\title{
HUBUNGAN ANTARA POLA ASUH ORANG TUA DENGAN KEPERCAYAAN DIRI REMAJA DI KELURAHAN KULIM
}

\author{
Jumaini ${ }^{1}$, Veny Elita ${ }^{2}$, Fathra Annis Nauli ${ }^{3}$ \\ ${ }^{1,2,3}$ Dosen Keperawatan Jiwa PSIK Universitas Riau \\ jumna_559@yahoo.co.id
}

\begin{abstract}
ABSTRAK
Kepercayaan diri merupakan aspek kepribadian manusia yang penting sebagai sarana untuk mengaktualisasikan potensi diri yang dimiliki. Pola asuh merupakan salah satu faktor eksternal yang amat mendasar bagi pembentukan rasa percaya diri. Penelitian ini bertujuan untuk mengetahui hubungan antara pola asuh orang tua dengan kepercayaan diri remaja di Kelurahan Kulim, Tenayan Raya, Pekanbaru dengan pendekatan kuantitatif studi, desain cross-sectional. Sampel berjumlah 100 orang remaja diambil menggunakan teknik stratified random sampling. Data diambil menggunakan kuesioner yang telah dilakukan uji validitas dan reliabilitas. Analisis data menggunakan uji chi-square dengan hasil terdapat hubungan yang bermakna antara pola asuh orang tua dengan kepercayaan diri remaja ( $\mathrm{p}$ value $0,00<\alpha 0,05$ ). Berdasarkan hasil penelitian diharapkan orang tua remaja dapat menerapkan pola asuh yang menunjang untuk peningkatan harga diri remaja dan kepada perawat puskesmas hendaknya dapat memberikan edukasi kepada masyarakat tentang pentingnya pola asuh yang menunjang pembentukan/peningkatan harga diri remaja.
\end{abstract}

Kata kunci : Percaya diri, pola asuh, remaja

\section{PENDAHULUAN}

Masa remaja merupakan salah satu tahap tumbuh kembang dalam siklus kehidupan manusia yang memiliki ciri-ciri khusus tersendiri. Masa remaja penuh dengan gejolak, karena pada masa tersebut terjadi berbagai perubahan baik fisik, psikologis maupun sosial. Masa ini juga masa yang amat penting dan menjadi penentu keberhasilan generasi penerus, jika diarahkan dengan benar dan diisi dengan sesuatu yang bermanfaat (Nurlis, 2008). Remaja, dalam perkembangannya mengalami berbagai stres psikologis, tekanan dari teman sebaya, pengaruh lingkungan dan gejolak emosi akibat perubahan dalam dirinya, sehingga terdapat masalah dalam membina hubungan dengan orang lain (orang tua, keluarga, guru, dan teman sebaya) dan masalah-masalah yang menekan jiwa remaja. Adanya permasalahan remaja tersebut dapat dikaitkan dengan kurangnya rasa percaya diri. 
Hasil penelitian Freda (2006) tentang masalah- masalah yang dihadapi remaja dalam berbagai aspek kehidupan didapatkan data bahwa masalah kepribadian yang paling sering muncul adalah masalah kurang percaya diri $(26,88 \%)$.

Kepercayaan diri merupakan aspek kepribadian manusia yang penting sebagai sarana untuk mengaktualisasikan potensi diri yang dimiliki. Percaya diri adalah suatu sikap yang memungkinkan individu mempunyai pandangan realistis dan positif tentang diri dan situasi mereka (WHO, 2003). Orang yang percaya diri yakin akan kemampuannya, dapat mengendalikan kehidupannya dan mempunyai harapan yang realistis. Rasa percaya diri diperlukan untuk membentuk jiwa yang sehat dan perilaku yang positif, sehingga remaja dapat menghadapi segala tantangan dalam hidupnya. Kepercayaan diri ini berpengaruh terhadap tugas perkembangan remaja dalam membentuk identitas diri. Kegagalan pada tahap ini akan menyebabkan bingung peran dan hambatan pada tugas perkembangan tahap selanjutnya (Keliat, Daulima, \& Farida, 2011).

Menurut Mastuti dan Aswi (2008) individu yang tidak percaya diri biasanya disebabkan karena individu tersebut tidak mendidik diri sendiri dan hanya menunggu orang melakukan sesuatu kepada dirinya. Percaya diri sangat bermanfaat untuk setiap keadaan, percaya diri juga menyatakan seseorang bertanggung jawab atas pekerjaannya. Karena semakin individu kehilangan kepercayaan diri, maka akan semakin sulit untuk memutuskan apa yang harus dilakukan untuk dirinya. Sikap percaya diri dapat dibentuk dengan belajar terus, tidak takut untuk berbuat salah, dan menerapkan pengetahuan yang sudah diketahui/dipelajari.

Santrock (2003) menyatakan rendahnya rasa percaya diri bisa menyebabkan masalah kesehatan jiwa, seperti harga diri rendah, isolasi sosial, depresi, anoreksia nervosa, dan bahkan masalah yang sangat fatal yaitu bunuh diri. Data Pusat Pencegahan dan Pengendalian 
Penyakit AS (CDC) menyebutkan bunuh diri adalah penyebab utama ketiga kematian bagi orang berusia antara 10 hingga 24 tahun. Sekitar 4.600 anak muda bunuh diri setiap tahun di AS (Reuters, 2013). Di Korea, menurut data statistik nasional tahun 2010, bunuh diri menjadi penyebab utama kematian pada usia remaja (Park \& Chung, 2013). Selama tahun 2012, di Indonesia, Komisi Perlindungan Anak (KPA) menerima 31 kasus percobaan bunuh diri pada usia13-17 tahun (remaja), 19 orang diantaranya meninggal (Fitriyani, 2012).

\section{Badan Pusat Statistik (BPS) Kota} Pekanbaru mencatat jumlah remaja di Kota Pekanbaru tahun 2012 adalah 897 ribu yang terdiri dari kelompok usia 10 - 14 tahun sebanyak 78 ribu dan usia 15 - 19 tahun sebanyak 86 ribu (BPS Kota Pekanbaru, 2012). Sedangkan pada tahun 2013, jumlah penduduk Kota Pekanbaru meningkat menjadi 964.558 jiwa dan jumlah remaja usia 10 - 14 tahun sebanyak 81.554 jiwa dan usia 15 - 19 tahun sebanyak 90,797 jiwa (BPS Kota Pekanbaru, 2012). Angka ini menunjukkan jumlah remaja yang cukup besar, yaitu sekitar $17 \%$ dari total jumlah penduduk.

Jumlah remaja yang cukup besar ini merupakan aset bangsa yang harus dijaga dan dioptimalkan tumbuh kembang dan kesehatannya baik fisik maupun mental. Fenomena yang ada sekarang ini, tampak beberapa karakteristik yang mengindikasikan banyaknya remaja yang mengalami kurang percaya diri. Beberapa karakteristik tersebut antara lain : memiliki motivasi yang rendah untuk berkompetisi, rendahnya motivasi remaja untuk mengembangkan diri dan berprestasi, dan kepribadian yang cenderung labil.

Beberapa penelitian menunjukkan bahwa permasalahan yang terjadi pada remaja disebabkan oleh kurangnya kepercayaan diri (Idrus \& Rohmiati, 2008). Dampak dari kurangnya kepercayaan diri pada remaja dapat meluas hingga perilaku menyimpang atau kenakalan remaja sebagai kompensasi dari rasa tidak percaya diri pada remaja. 
Uraian di atas menunjukkan betapa pentingnya kepercayaan diri pada seorang remaja, namun di sisi lain seorang remaja sangat berisiko untuk mengalami kepercayaan diri yang kurang. Berdasarkan hal itu maka penulis tertarik untuk melakukan penelitian tentang hubungan antara pola asuh orang tua dengan kepercayaan diri pada remaja di Kelurahan Kulim, Kecamatan Tenayan raya, Kota Pekanbaru.

\section{METODE PENELITIAN}

Jenis penelitian ini adalah penelitian kuantitatif dengan desain crosssectional. Dalam penelitian crosssectional peneliti melakukan observasi atau pengukuran variabel pada satu saat tertentu. Tiap subyek hanya diobservasi satu kali dan pengukuran variabel subyek dilakukan pada saat pemeriksaan tersebut (Sastroasmoro \& Ismael, 2008).

Penelitian dilakukan untuk mengetahui hubungan antara pola asuh orang tua dengan kepercayaan diri remaja. Selanjutnya pengambilan sampel dilakukan dengan menggunakan stratified random sampling kepada sebanyal 100 orang remaja. Karakteristik remaja yang menjadi responden pada penelitian ini adalah 1) berusia 13-18 tahun, 2) masih sekolah, dan 3) tinggal bersama orang tuanya.

Alat pengumpul data yang digunakan dalam penelitian ini adalah kuesioner yang telah dilakukan uji validitas dan reliabilitas. Kuesioner terdiri dari 3 (tiga) bagian, yaitu data demografi remaja, kuesioner untuk mengetahui pola asuh orang tua, dan kuesioner untuk mengetahui kepercayaan diri remaja. Sebelum penelitian dilakukan, semua responden yang menjadi subyek penelitian diberi informasi tentang rencana dan tujuan penelitian. Setiap responden diberi hak penuh untuk menyetujui atau menolak menjadi responden dengan cara menandatangani informed concent atau surat pernyataan kesediaan yang telah disiapkan oleh peneliti. Pengambilan data dilakukan pada bulan Juli - Agustus 2014. Analisa data secara univariat menggunakan distribusi frekuensi dan 
analisa bivariat menggunakan uji chisquare.

\section{HASIL PENELITIAN}

Tabel 1. Karakteristik Jenis Kelamin Responden

\begin{tabular}{ccc}
\hline $\begin{array}{c}\text { Jenis } \\
\text { Kelamin }\end{array}$ & $\begin{array}{c}\text { Frekuensi } \\
(\mathbf{f})\end{array}$ & $\begin{array}{c}\text { Persentase } \\
(\boldsymbol{\%})\end{array}$ \\
\hline Laki-laki & 47 & 47 \\
Perempuan & 53 & 53 \\
\hline Total & 100 & 100 \\
\hline
\end{tabular}

Berdasarkan tabel 1 di atas menunjukkan bahwa sebagian responden dalam penelitian ini berjenis kelamin perempuan, yaitu sebanyak 53 orang remaja (53\%).
Tabel 2. Karakteristik Usia Responden Usia Frekuensi Persentase

\begin{tabular}{ccc} 
& (f) & $(\%)$ \\
\hline 13 tahun & 17 & 17 \\
14 tahun & 16 & 16 \\
15 tahun & 20 & 20 \\
16 tahun & 21 & 21 \\
17 tahun & 23 & 23 \\
18 tahun & 3 & 3 \\
\hline Total & 100 & 100 \\
\hline
\end{tabular}

Berdasarkan tabel 2 di atas menunjukkan bahwa sebagian besar responden dalam penelitian ini berusia 17 tahun, yaitu sebanyak 23 orang remaja $(23 \%)$.

Tabel 3. Hubungan antara Pola Asuh dengan Kepercayaan Diri Remaja

\begin{tabular}{lcccccccc}
\hline \multirow{2}{*}{ Pola Asuh } & \multicolumn{3}{c}{ Kepercayaan Diri Remaja } & \multicolumn{2}{c}{ Total } & \multirow{2}{*}{ P Value } \\
\cline { 2 - 6 } & \multicolumn{2}{c}{ Tinggi } & \multicolumn{2}{c}{ Sedang } & & & \\
\cline { 2 - 7 } & $\mathrm{N}$ & $\%$ & $\mathrm{~N}$ & $\%$ & $\mathrm{~N}$ & $\%$ & \\
\hline Demokratis & 48 & 73,9 & 17 & 26,1 & 65 & 100 & \multirow{2}{*}{0,00} \\
\hline Otoriter & 0 & 0 & 35 & 100 & 35 & 100 & \\
\hline Jumlah & 48 & 73,9 & 52 & 26,1 & 100 & 100 & \\
\hline
\end{tabular}

Berdasarkan tabel 3 di atas menunjukkan bahwa terdapat 48 orang remaja $(73,9 \%)$ mendapatkan pola asuh demokratis dan memiliki kepercayaan diri yang tinggi. Remaja yang mendapatkan pola asuh otoriter sebanyak 35 orang memiliki kepercayaan diri kategori sedang.
Berdasarkan uji statistik, diperoleh hasil $\mathrm{p}$ value $(0,00)<\alpha(0,05)$ sehingga dapat disimpulkan terdapat hubungan yang bermakna antara pola asuh dengan kepercayaan diri remaja. 


\section{PEMBAHASAN}

Hasil penelitian menunjukkan bahwa terdapat hubungan yang bermakna antara pola asuh dengan kepercayaan diri remaja ( $\mathrm{p}$ value $<\alpha$ ). Hasil penelitian ini sesuai dengan penelitian Idrus dan Rohmiati (2008) yang menyatakan terdapat hubungan yang bermakna antara kepercayaan diri remaja dengan pola asuh orang tua etnis Jawa. Hasil penelitian Wildan (2013) juga menunjukkan bahwa terdapat hubungan yang bermakna antara pola asuh orang tua dengan konsep diri remaja.

Kepercayaan diri merupakan suatu sikap atau perasaan yakin akan kemampuan diri sendiri sehingga seseorang tidak terpengaruh oleh orang lain (Lauster, 1999). Percaya diri juga didefinisikan sebagai sikap positif seorang individu yang memampukan dirinya untuk mengembangkan penilaian positif, baik terhadap diri sendiri maupun terhadap lingkungan/situasi yang dihadapinya (Rini, 2002). Kepercayaan diri dipengaruhi dari tiap tahap perkembangan psikososial individu. Erik Erikson yang di kutip oleh Towsend (2009) menjelaskan perkembangan psikososial mempunyai delapan tahap perkembangan, yaitu masa bayi, kanak-kanak, pra sekolah, usia sekolah, remaja, dewasa muda, dewasa dan lanjut usia. Perkembangan psikososial remaja adalah kemampuan remaja untuk mencapai identitas dirinya yang meliputi peran, tujuan pribadi, dan keunikan atau ciri khas diri (Keliat, Helena, \& Farida, 2011). Bila tidak dapat mencapai kemampuan tersebut individu akan mengalami bingung peran yang berdampak pada rapuhnya kepribadian, sehingga akan terjadi gangguan konsep diri, termasuk gangguan kepercayaan diri.

Salah satu faktor eksternal yang amat mendasar bagi pembentukan rasa percaya diri adalah pola asuh (Rini, 2002). Pola asuh adalah pola pengasuhan anak yang berlaku dalam keluarga, yaitu cara keluarga membentuk perilaku anak sesuai dengan norma dan nilai yang baik dan sesuai dengan kehidupan masyarakat (Hardywinoto \& Setiabudhi, 2003). 
Pola asuh anak meliputi interaksi antara orang tua dengan anak dalam bentuk pemenuhan kebutuhan fisik dan psikologis.

Hasil penelitian ini juga menunjukkan bahwa sebagian besar responden mendapatkan pola asuh demokratis dengan kepercayaan diri tinggi $(73,9 \%) . \quad$ Hurlocks menjelaskan bahwa salah satu faktor yang mempengaruhi perkembangan kepercayaan diri pada masa remaja adalah pola asuh yaitu pola asuh yang demokratis.

Pada pola asuh demokratis, anak atau remaja diberikan kebebasan dan tanggung jawab untuk mengemukakan pendapatnya dan melakukan apa yang sudah menjadi tanggung jawabnya. Pola asuh demokratis menjunjung keterbukaan, pengakuan terhadap pendapat anak, dan kerja sama (Baumrind dalam Fathi, 2010). Ciri yang kental dari pola asuh ini adalah adanya diskusi antara anak dan orang tua. Orang tua mengakui eksistensi anaknya. Kebebasan berkespresi diberikan pada anak dengan tetap berada dibawah pengawasan orang tua.

Arkoff dalam Fathi (2010) menyatakan bahwa anak yang dididik dengan cara demokratis umumnya cenderung mengungkapkan agresifitasnya dalam tindakan yang konstruktif atau dalam bentuk kebencian yang sementara. Hasil penelitian Rohner, Khalaque, dan Counoyer (2007) menunjukkan bahwa pola asuh orang tua yang menerima akan membuat anak merasa disayang, dilindungi, dianggap berharga, dan diberi dukungan oleh orang tuanya. Pola asuh ini sangat baik untuk mendukung pembentukan kepribadian yang pro sosial, percaya diri, dan mandiri tetapi sangat peduli dengan lingkungannya.

\section{KESIMPULAN}

1. Sebagian besar responden berjenis kelamin perempuan $(53 \%)$

2. Usia responden yang paling banyak adalah 17 tahun (23\%)

3. Terdapat hubungan yang bermakna antara pola asuh orang tua dengan kepercayaan diri remaja ( $\mathrm{p}$ value < $\alpha)$ 


\section{SARAN}

Diharapkan orang tua remaja dapat menerapkan pola asuh yang menunjang untuk peningkatan harga diri remaja dan kepada perawat puskesmas hendaknya dapat memberikan edukasi kepada masyarakat tentang pentingnya pola asuh yang menunjang pembentukan/peningkatan harga diri remaja.

\section{REFERENSI}

BPS Kota Pekanbaru. (2012). Jumlah penduduk Kota Pekanbaru dirinci menurut kelompok umur dan jenis kelamin. Diperoleh tanggal 3 Oktober 2013.

Fathi. (2010). Mendidik anak dengan Al-Qur'an. Bandung : Oasis.

Freda, AB (2006). Masalah-masalah yang dihadapi remaja dalam berbagai aspek kehidupannya .Skripsi (tidak dipublikasikan). Jakarta : Fakultas Psikologi Universitas Indonesia.

Hardywinoto \& Setiabudhi, T. (2003). Anak unggul berotak prima. Jakarta : Gramedia pustaka utama.

\footnotetext{
Hurlock, E.B (1999) . Psikologi Perkembangan Suatu Pendekatan Sepanjang Rentang Kehidupan. Edisi 5 .Surabaya.
}

PT. Gelora Aksara Pratama Erlangga.

Idris, M. \& Rohmiati, A. (2008). Hubungan kepercayaan diri remaja dengan pola asuh orang tua etnis Jawa. http://kajian.uii.ac.id/. Diakses tanggal 4 Februari 2014.

Keliat, B.A., Daulima, N.H.C, \& Farida, P. (2011). Manajemen keperawatan psikososial \& kader kesehatan jiwa CMHN (intermediate course). Jakarta : EGC.

Mastuti \& Aswi. (2008). 50 kiat percaya diri. Jakarta : PT. Buku Kita.

Notoatmodjo, S. (2005). Metodologi penelitian kesehatan. Jakarta : Rineka cipta.

Nurlis. (2008). Pengaruh latihan pengembangan kepercayaan diri terhadap rasa percaya diri remaja. Tesis FIK UI. Tidak dipublikasikan.

Reuters. (2013). Bunuh diri mengusik remaja AS. Diperoleh tanggal 10 Januari 2014 dari www.shnews.co/detile-13217-

Rini, J.F (2002) . Memupuk Rasa Percaya Diri, http://digilib.itb.ac.id, diperoleh tanggal 17 Februari 2014.

Rohner, R.P, Khaleque, A, \& Cournoyer, D.E, (2007). Introduction to parental acceptance rejection theory, methods, evidence, and implications. Diperoleh tanggal 
5 Oktober 2014 dari http://cspar.uconn.edu.com

Santrock, J.W. (2003). Life Span Development ( terjemahan ). Boston: Mc Graw Hill.

Sastroasmoro, S. \& Ismael, S. (2008). Dasar-dasar metodologi penelitian klinis. Jakarta : sagung Seto.

Townsend, M.C. (2009). Psychiatric Mental Health Nursing Concepts of Care in EvidenceBased Practice. $6^{\text {th }}$ ed. Philadelphia: F.A. Davis Company.
Wildan. (2013).Pengaruh pola asuh orang tua dan peer group terhadap konsep diri remaja tentang perilaku seksual. Diperoleh tanggal 24 februari 2014 dari http://repository.usu.ac.id/bitstr eam/123456789/37091/1/Appen dix.pdf.

WHO (2003) Adolescence Mental Health Promotion. New Delhi : South East Asia Regional Office of the World Health Organization 